\title{
Efektivitas Penerimaan Negara Bukan Pajak Usaha Pertambangan Di Kabupaten Manokwari
}

\author{
Juanita R. Horman ${ }^{1}$ \\ ${ }^{1}$ Program Studi Teknik Pertambangan, Universitas Papua
}

Received: Januari 2019; Accepted: Februari 2019; Published: Maret 2019

\begin{abstract}
Abstrak
Penerimaan Negara Bukan Pajak (PNBP) adalah seluruh penerimaan pemerintah yang tidak berasal dari penerimaan perpajakan, yang salah satunya berasal dari penerimaan sumber daya alam. Kabupaten Manokwari memiliki potensi sumber daya mineral dan batubara yang diharapkan dapat menggerakkan perekonomian daerah melalui PNBP usaha pertambangan. Tujuan penelitian ini adalah untuk menghitung potensi dan efektivitas PNBP usaha pertambangan di Kabupaten Manokwari. Hasil penelitian menunjukkan bahwa potensi PNBP Usaha Pertambangan tahun 2014 adalah sebesar Rp. 43,776,463,320 dan sebesar Rp. 57,099,734,765 pada tahun 2015. Sedangkan efektivitas PNBP Usaha Pertambangan di Kabupaten Manokwari tahun 2014 dan 2015 bernilai $0 \%$ atau tidak efektif.
\end{abstract}

Kata kunci: penerimaan negara bukan pajak, pertambangan, Manokwari

\begin{abstract}
Non-Tax Revenues are the total of government revenues that are not sourced from general taxation, in which revenue from natural resources become one important source. Manokwari regency has natural resource and coal potentials, that is expected to drive local economy through the utilization of its non-tax revenues. This research aims to calculate the potentials and effectivity of non-tax revenues sourced from mining activities in Manokwari regency. The findings show that non-tax revenue potential is approximately IDR 43.7 billion in 2014, and increases just over IDR 57 billion in 2015. Nevertheless, effectivity of the non-tax revenue derived from mining activities in Manokwari is zero percent, which means ineffective.
\end{abstract}

Keywords: non-tax revenue, mining, Manokwari

How to Cite: Horman, J. R. (2019). Efektivitas Penerimaan Negara Bukan Pajak Usaha Pertambangan Di Kabupaten Manokwari. JFRES: Journal of Fiscal and Regional Economy Studies, 2 (1), 21 - 26. 


\section{PENDAHULUAN}

Pada dasarnya, penerimaan negara terbagi atas dua jenis penerimaan, yaitu penerimaan dari pajak dan penerimaan bukan pajak, atau yang disebut Penerimaan Negara Bukan Pajak (PNBP). Menurut UU No. 20 Tahun 1997 tentang PNBP, PNBP adalah seluruh penerimaan Pemerintah Pusat yang tidak berasal dari penerimaan perpajakan (UU No 20/1997).

Dalam Anggaran Pendapatan dan Belanja Negara (APBN) dikenal 4 kategori besar PNBP, yaitu penerimaan sumber daya alam, pendapatan bagian laba Badan Usaha Milik Negara, PNBP lainnya dan pendapatan Badan Layanan Umum.

Di antara ke empat kategori tersebut, PNBP yang dianggap paling potensial adalah penerimaan sumber daya alam dari sektor pertambangan.

Secara keseluruhan di Indonesia, kontribusi PNBP masih rendah terhadap penerimaan negara. Kontribusi PNBP terhadap pendapatan APBN $(26,99 \%)$ lebih kecil dari pajak $(72,72 \%)$ secara rata-rata dalam kurun tahun 2007 - 2012. Untuk
PNBP Pertambangan Umum hanya sebesar Rp.16,3 Triliun $(5,16 \%)$ dari PNBP keseluruhan sebesar Rp.324,5 Triliun (Kemenkeu, 2013).

Kabupaten Manokwari memiliki potensi sumber daya mineral dan batubara yang diharapkan dapat menggerakkan perekonomian daerah. Berdasarkan data dari Perekonomian Daerah (PEREKDA) Sekretariat Daerah (Setda) Kabupaten Manokwari dan Dinas Pertambangan dan Energi Provinsi Papua Barat, di Kabupaten Manokwari telah diterbitkan 24 Ijin Usaha Pertambangan. Dengan diterbitkannya Ijin Usaha Pertambangan tersebut diharapkan pemegang Ijin Usaha Pertambangan dapat melaksanakan seluruh kewajiban keuangan pelaku usaha pertambangan, salah satunya adalah membayar iuran tetap dan royalti yang akan menjadi sumber PNBP di Kabupaten Manokwari.

Tujuan dari penelitian ini adalah untuk menghitung nilai potensi dan efektivitas PNBP usaha pertambangan di Kabupaten Manokwari tahun 2014-2015.

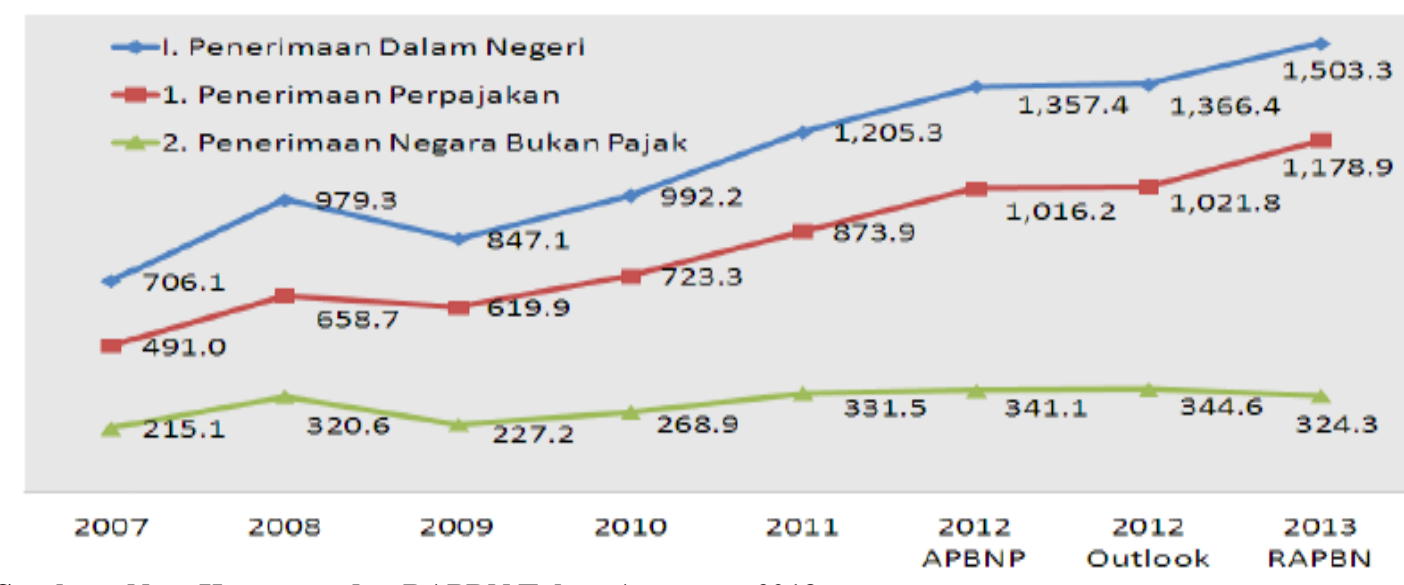

Sumber : Nota Keuangan dan RAPBN Tahun Anggaran 2013

Gambar 1. Kontibusi PNBP Terhadap Penerimaan Negara (Rp Triliun)

\section{TINJAUAN PUSTAKA}

\section{Jenis PNBP Usaha Pertambangan}

Jenis PNBP usaha pertambangan adalah sebagai berikut:

1. Iuran tetap, merupakan iuran yang dibayarkan kepada negara sebagai imbalan atas kesempatan eksplorasi, studi kelayakan dan eksploitasi pada suatu wilayah usaha pertambangan.

$$
\text { Iuran tetap }=\text { luas wilayah IUP } \times \text { tarif }
$$

2. Royalti, merupakan iuran produksi yang dibayarkan kepada negara atas hasil yang diperoleh dari usaha pertambangan.

$$
\text { Royalti }=\text { penjualan } \times \text { tarif }
$$

\section{Potensi PNBP Usaha Pertambangan}

Potensi PNBP usaha pertambangan menggambarkan besarnya PNBP sektor pertambangan yang sesungguhnya dapat dimanfaatkan di suatu wilayah.

\section{PNBP Usaha Pertambangan Terutang}

PNBP yang terutang adalah PNBP yang harus dibayar pada suatu saat, atau dalam suatu periode tertentu menurut ketentuan peraturan perundangundangan (PP No. 29 Tahun 2009).

Berdasarkan PP No. 29 Tahun 2009, PNBP yang terutang dapat dihitung menggunakan persamaan berikut: 
PNBP yang terutang $=$ Po $\times\left\{(1+2 \%)^{\mathrm{n}}\right\}$

Keterangan:

$$
\begin{array}{ll}
\mathrm{Po} & =\text { Pokok PNBP terutang } \\
\mathrm{n} & =\text { Jumlah bulan keterlambatan }
\end{array}
$$

\section{Efektivitas}

Efektivitas merupakan suatu ukuran (umumnya dalam persen) yang digunakan untuk membandingkan antara capaian/realisasi dengan target yang telah ditetapkan sebelumnya. Dalam kaitannya dengan PNBP usaha pertambangan, maka efektivitas PNBP mengukur hubungan antara hasil pungutan (realisasi) PNBP dengan potensi yang sesungguhnya.

\section{METODE PENELITIAN}

Penelitian ini merupakan penelitian deskriptif dengan pendekatan kuantitatif. Penelitian ini dilaksanakan di Kabupaten Manokwari Provinsi Papua Barat. Data yang dianalisis merupakan data sekunder, berupa data iuran tetap dan royalti dari usaha pertambangan.

Untuk mengetahui potensi PNBP usaha pertambangan, formula yang digunakan adalah sebagai berikut:

$$
\text { Potensi }=\Sigma \text { iuran tetap }+\Sigma \text { royalty }
$$

Sedangkan efektivitas PNBP dihitung dengan membandingkan realisasi PNBP dengan potensi PNBP usaha pertambangan (Iktama \& Pusposari,
2013), yang secara matematis dirumuskan sebagai berikut:

$$
\begin{gathered}
E f=\frac{\text { Realisasi } P N B P \text { pertambangan }}{\text { Potensi } P N B P \text { pertambangan }} \\
\times 100 \%
\end{gathered}
$$

Keterangan:

Ef = Efektivitas PNBP

Kriteria efektivitas PNBP usaha pertambangan berdasarkan Kepmendagri No. 690.900.327 Tahun 1996 (Kemendagri, 1996) dapat dilihat pada Tabel 1.

Tabel 1. Kriteria Efektivitas

\begin{tabular}{cc}
\hline Presentase & Kriteria \\
\hline$>100 \%$ & Sangat Efektif \\
$90 \%-100 \%$ & Efektif \\
$80 \%-90 \%$ & Cukup Efektif \\
$60 \%-80 \%$ & Kurang Efektif \\
\hline
\end{tabular}

\section{HASIL DAN PEMBAHASAN}

\section{Potensi PNBP IUP Eksplorasi dan Operasi Produksi}

Potensi PNBP IUP Eksplorasi dan Operasi Produksi di Kabupaten Manokwari dihitung berdasarkan jumlah IUP yang diterbitkan oleh Pemerintah Daerah Kabupaten Manokwari dalam hal ini PEREKDA Setda Kabupaten Manokwari dan Dinas Pertambangan dan Energi Provinsi Papua Barat, dapat dilihat pada Tabel 2 dan 3.

Tabel 2. Potensi PNBP IUP Eksplorasi

\begin{tabular}{ccccc}
\hline \multirow{2}{*}{ No } & \multirow{2}{*}{ Bahan Galian } & \multirow{2}{*}{ Jumlah IUP } & \multicolumn{2}{c}{ Iuran Tetap (Rp) } \\
\cline { 4 - 5 } 1 & Batubara & 8 & $3,919,844,000$ & $\mathbf{2 0 1 5}$ \\
2 & Emas DMP & 8 & $6,702,752,000$ & $5,112,840,000$ \\
3 & Nikel & 1 & $1,746,850,000$ & $8,742,720,000$ \\
\hline \multicolumn{2}{c}{ Jumlah } & 17 & $12,369,446,000$ & $2,278,500,000$ \\
\hline
\end{tabular}

Sumber: Data diolah

Jumlah IUP Eksplorasi yang diterbitkan oleh Pemerintah Daerah Kabupaten Manokwari pada tahun 2014 dan 2015, untuk Batubara dan Emas Dan Mineral Pengikutnya (DMP), masingmasing berjumlah delapan ijin, dan satu ijin untuk Nikel. Total Potensi PNBP berdasarkan jumlah IUP Eksplorasi yang seharusnya diterima oleh Pemerintah Daerah Kabupaten Manokwari pada tahun 2014 adalah sebesar Rp. $12,369,446,000$ dan meningkat Rp. 16,134,060,000 pada tahun 2015.

\begin{tabular}{|c|c|c|c|c|}
\hline \multirow{2}{*}{ No } & \multirow{2}{*}{ Bahan Galian } & \multirow{2}{*}{ Jumlah IUP } & \multicolumn{2}{|c|}{ Iuran Tetap (Rp) } \\
\hline & & & 2014 & 2015 \\
\hline 1 & Antimoni DMP & 2 & $1,656,460,000$ & $2,160,600,000$ \\
\hline 2 & Batubara & 1 & $688,160,000$ & $897,600,000$ \\
\hline 3 & Mangan DMP & 4 & $2,068,574,000$ & $2,698,140,000$ \\
\hline & Jumlah & 7 & $4,413,194,000$ & $5,756,340,000$ \\
\hline
\end{tabular}

Selain IUP Eksplorasi, dihitung pula potensi PNBP IUP Operasi Produksi yang diterbitkan oleh Pemerintah Daerah Kabupaten Manokwari.

Tabel 3. Potensi PNBP IUP Operasi Produksi

Sumber: Data diolah 
Jumlah IUP Operasi Produksi yang diterbitkan jauh lebih sedikit dibandingkan IUP Eksplorasi. Untuk Antimoni DMP berjumlah dua ijin, Batubara satu ijin dan empat ijin untuk Mangan DMP.
Total Potensi PNBP berdasarkan jumlah IUP Operasi Produksi yang seharusnya diterima oleh Pemerintah Daerah Kabupaten Manokwari pada tahun 2014 adalah sebesar Rp. 4,413,194,000 dan pada tahun 2015 meningkat menjadi Rp. 5,756,340,000.

Tabel 4. Total Potensi PNBP IUP Eksplorasi dan Operasi Produksi

\begin{tabular}{|c|c|c|c|}
\hline \multirow{2}{*}{ No } & \multirow{2}{*}{ Jenis IUP } & \multicolumn{2}{|c|}{ Iuran Tetap (Rp) } \\
\hline & & 2014 & 2015 \\
\hline 1 & Eksplorasi & $12,369,446,000$ & $16,134,060,000$ \\
\hline 2 & Operasi Produksi & $4,413,194,000$ & $5,756,340,000$ \\
\hline & Jumlah & $16,782,640,000$ & $21,890,400,000$ \\
\hline
\end{tabular}

\section{Sumber: Data diolah}

Berdasarkan IUP Eksplorasi dan Operasi produksi tersebut, total Potensi PNBP yang seharusnya diterima oleh Pemerintah Daerah Kabupaten Manokwari pada tahun 2014 adalah sebesar Rp. 16,782,640,000 dan meningkat menjadi Rp. 21,890,400,000 pada tahun 2015.

\section{PNBP IUP Eksplorasi dan Operasi Produksi Terutang}

Menurut PP No. 29 Tahun 2009, Penerimaan Negara Bukan Pajak menjadi terutang sebelum Wajib Bayar menerima manfaat atas kegiatan Instansi Pemerintah atau sesudah Wajib Bayar menerima manfaat atas kegiatan Instansi Pemerintah.

Wajib Bayar wajib membayar seluruh PNBP yang Terutang secara tunai paling lambat pada saat jatuh tempo pembayaran.
Dalam hal pembayaran PNBP yang Terutang melampaui jatuh tempo pembayaran yang ditetapkan, Wajib Bayar dikenakan sanksi administrasi berupa denda sebesar $2 \%$ per bulan dari bagian yang terutang dan bagian dari bulan dihitung satu bulan penuh. Sanksi administrasi berupa denda sebagaimana dimaksud dikenakan untuk paling lama 24 bulan. PNBP terutang dapat dilihat pada Tabel 5, 6 dan 7 .

PNBP yang terutang berdasarkan jumlah IUP Eksplorasi yang seharusnya dibayarkan oleh Wajib Bayar kepada Pemerintah Daerah Kabupaten Manokwari pada tahun 2014 adalah sebesar Rp. 19,895,477,701 dan pada tahun 2015 sebesar Rp. 25,950,623,089. Sedangkan untuk IUP Operasi Produksi pada tahun 2014 adalah sebesar Rp. 7,098,345,618 dan sejumlah Rp. 9,258,711,676 pada tahun 2015.

Tabel 5. PNBP IUP Eksplorasi Terutang

\begin{tabular}{cccrc}
\hline \multirow{2}{*}{ No } & \multirow{2}{*}{ Bahan Galian } & \multirow{2}{*}{ Jumlah IUP } & $\mathbf{2 0 1 4}$ & \multicolumn{2}{c}{ Iuran Tetap (Rp) } \\
\cline { 3 - 5 } 1 & Batubara & 8 & $6,304,823,101$ & $8,223,682,306$ \\
2 & Emas DMP & 8 & $10,780,955,990$ & $14,062,116,509$ \\
3 & Nikel & 1 & $2,809,698,609$ & $3,664,824,272$ \\
\hline & Jumlah & 17 & $19,895,477,701$ & $25,950,623,089$ \\
\hline
\end{tabular}

Sumber: Data diolah

Tabel 6. PNBP IUP Operasi Produksi Terutang

\begin{tabular}{ccccc}
\hline \multirow{2}{*}{ No } & \multirow{2}{*}{ Bahan Galian } & \multirow{2}{*}{ Jumlah IUP } & $\mathbf{2 0 1 4}$ & Iuran Tetap (Rp) \\
\cline { 3 - 5 } 1 & Antimoni DMP & 2 & $2,664,311,966$ & $3,475,189,521$ \\
2 & Batubara & 1 & $1,106,862,177$ & $1,443,733,275$ \\
3 & Mangan DMP & 4 & $3,327,171,474$ & $4,339,788,880$ \\
\hline & Jumlah & 7 & $7,098,345,618$ & $9,258,711,676$ \\
\hline
\end{tabular}

Sumber: Data diolah

Tabel 7. Total PNBP IUP Eksplorasi dan Operasi Produksi Terutang

\begin{tabular}{clrr}
\hline \multirow{2}{*}{ No } & \multirow{2}{*}{ Jenis IUP } & \multicolumn{2}{c}{ Iuran Tetap (Rp) } \\
\cline { 3 - 4 } 1 & Eksplorasi & $\mathbf{2 0 1 4}$ & $\mathbf{2 0 1 5}$ \\
2 & Operasi Produksi & $19,895,477,701$ & $25,950,623,089$ \\
\hline \multicolumn{2}{c}{ Jumlah } & $7,098,345,618$ & $9,258,711,676$ \\
\hline
\end{tabular}

Sumber: Data diolah 
Maka total PNBP yang terutang yang seharusnya dibayarkan oleh Wajib Bayar kepada Pemerintah Daerah Kabupaten Manokwari pada tahun 2014 adalah sebesar Rp. 26,993,823,320 dan meningkat menjadi Rp. 35,209,334,765 pada tahun 2015.

\section{Potensi Dan Realisasi PNBP Usaha Pertambangan}

Potensi PNBP usaha pertambangan, meliputi Iuran tetap (IUP Eksplorasi dan Operasi Produksi) dan royalty.

Pada saat penelitian ini dilakukan, tidak ada iuran produksi yang dibayarkan kepada negara atas hasil yang diperoleh dari usaha pertambangan (royalty $=0$ ), hal ini disebabkan oleh belum adanya perusahaan yang melakukan kegiatan penambangan sekalipun telah memiliki IUP Operasi Produksi. Sehingga hanya Iuran Tetap dan Iuran Tetap Terutanglah yang berkontribusi terhadap potensi PNBP Usaha Pertambangan. Potensi PNBP Usaha Pertambangan dapat dilihat pada Tabel 8.

Realisasi adalah hasil pungutan atau jumlah iuran tetap baik itu IUP Eksplorasi maupun IUP Operasi Produksi yang telah dibayarkan Wajib Bayar kepada Pemerintah Daerah Kabupaten Manokwari.

Berdasarkan Tabel 9, pada tahun 2014 dan 2015, Wajib Bayar tidak melaksanakan kewajibannya yaitu melakukan pembayaran Iuran Tetap Usaha Pertambangan (realisasi $=0$ ).

Tabel 8. Potensi PNBP Usaha Pertambangan

\begin{tabular}{|c|c|c|c|}
\hline \multirow{2}{*}{ No } & \multirow{2}{*}{ Potensi } & \multicolumn{2}{|c|}{ PNBP (Rp) } \\
\hline & & 2014 & 2015 \\
\hline 1 & Iuran Tetap & $16,782,640,000$ & $21,890,400,000$ \\
\hline 2 & Royalty & 0 & 0 \\
\hline 3 & Iuran Tetap Terutang & $26,993,823,320$ & $35,209,334,765$ \\
\hline & Jumlah & $43,776,463,320$ & $57,099,734,765$ \\
\hline
\end{tabular}

Sumber: Data diolah

Tabel 9. Potensi dan Realisasi PNBP Usaha Pertambangan

\begin{tabular}{cllrr}
\hline \multirow{2}{*}{ No } & \multirow{2}{*}{ Potensi } & \multicolumn{2}{c}{ PNBP (Rp) } \\
\cline { 3 - 5 } & & & $\mathbf{2 0 1 4}$ & $\mathbf{2 0 1 5}$ \\
\hline 1 & Potensi & & $43,776,463,320$ & $57,099,734,765$ \\
2 & Realisasi & & 0 & 0 \\
\hline & & Selisih & $43,776,463,320$ & $57,099,734,765$ \\
\hline
\end{tabular}

Sumber: Data diolah

Efektivitas PNBP Usaha Pertambangan

$$
\begin{aligned}
\text { Ef } 2014= & \frac{\text { Realisasi PNBP 2014 }}{\text { Potensi PNBP 2014 }} \times 100 \% \\
& =\frac{0.00}{43,776,463,320.53} \times 100 \% \\
& =0.00 \% \\
\text { Ef } 2015= & \frac{\text { Realisasi PNBP 2015 }}{\text { Potensi PNBP 2015 }} \times 100 \% \\
& =\frac{0.00}{57,099,734,765.91} \times 100 \% \\
& =0.00 \%
\end{aligned}
$$

Berdasarkan kriteria pada Tabel 1, perbandingan antara hasil pungutan (realisasi) PNBP dengan potensi yang sesungguhnya dari PNBP Usaha Pertambangan menunjukan pembayaran Iuran Tetap dan royalty tidak efektif sama sekali, dalam hal ini nilai efektivitas yang diperoleh pada tahun 2014 dan 2015 sebesar 0\%.
Kelemahan dalam proses penagihan kemungkinan menjadi salah satu penyebab tidak tertagihkannya semua piutang negara (iuran tetap dan royalti) oleh pemerintah kepada Wajib Bayar. Kelonggaran dalam penagihan pembayaran berpotensi memberikan ruang bagi Wajib Bayar untuk menunda pembayaran. Di sisi lain, hal ini dapat menghambat pemerintah dalam memberikan sanksi atas keterlambatan pembayaran.

Alasan Wajib Bayar tidak melakukan pembayaran atas Iuran Tetap karena adanya perubahan PP No. 45 Tahun 2003 tentang Tarif Atas Jenis Penerimaan Negara Bukan Pajak Yang Berlaku Pada Departemen Energi dan Sumber Daya Mineral menjadi PP No. 9 Tahun 2012 tentang Jenis dan Tarif Atas Jenis PNBP Yang Berlaku Pada Kementerian Energi dan Sumber Daya Mineral.

Contohnya pada PP No. 45 Tahun 2003, Iuran Tetap Eksplorasi untuk Usaha Pertambangan Umum pada tahun pertama adalah sebesar Rp. 
2,000/ha, pada PP No. 9 Tahun 2012 menjadi USD 2 per ha/tahun. Perubahan tarif untuk Iuran Tetap ini dianggap membebani Wajib Bayar.

\section{Upaya Pencapaian PNBP Usaha Pertambangan}

Upaya yang dapat dilakukan oleh Pemerintah Daerah Kabupaten Manokwari untuk mencapai PNBP Usaha Pertambangan sesuai dengan potensi adalah melalui perbaikan sistem, meliputi perbaikan dasar pengenaan, metode perhitungan, perbaikan sistem penagihan, pelaporan dan pengawasan, yaitu:

1. Melakukan evaluasi yaitu dengan menginventarisasi dan memverifikasi dokumen perijinan (administrasi, teknis dan kewajiban keuangan), sehingga diperoleh data yang akurat terkait status Clear and Clean $(\mathrm{CnC})$ maupun non $\mathrm{CnC}$.

2. Membangun sistem pengelolaan PNBP Usaha Pertambangan berbasis IT yang antara lain memuat database pelaku usaha, database lokasi usaha berbasis spasial berikut sistem monitoring dan evaluasinya, database produksi, database penjualan dan sistem ini diharapkan terintegrasi dengan semua stakeholder terkait.

3. Melakukan monitoring kepada Dinas Pertambangan dan Energi Provinsi Papua Barat terkait pelaksanaan kewajiban pelaporan pengelolaan PNBP dan pelaksanaan kewajiban pembayaran/ penyetoran PNBP Usaha Pertambangan.

4. Melakukan audit pada seluruh Wajib Bayar (Pemegang IUP).

5. Menerapkan sanksi atas terlambat bayar, kurang bayar atau tidak bayar yang lebih berat sehingga ada efek jera. Ketentuan yang mengatur tentang batas maksimum denda yang diberlakukan atas ketidaktaatan yakni maksimal selama 24 bulan menjadikan celah yang meringankan dan dianggap mendorong perusahaan menunda pembayaran.

\section{KESIMPULAN}

Nilai potensi PNBP Usaha Pertambangan pada tahun 2014 adalah sebesar Rp. 43,776,463,320 dan meningkat menjadi Rp. 57,099,734,765 pada tahun 2015.

Tidak adanya pembayaran PNBP Usaha Pertambangan oleh Wajib Bayar menyebabkan
Efektivitas PNBP Usaha Pertambangan di Kabupaten Manokwari tahun 2014 dan 2015 bernilai $0 \%$ atau tidak efektif.

Perbaikan sistem pengelolaan PNBP, yang meliputi perbaikan dasar pengenaan, metode perhitungan, sistem penagihan, pelaporan dan pengawasan, sangat diperlukan dalam rangka meningkatkan efektivitas PNBP usaha pertambangan di Kabupaten Manokwari.

\section{UCAPAN TERIMA KASIH}

Penulis mengucapkan terima kasih kepada Beni Yulikawati atas bantuannya dalam pengambilan data. Ucapan terima kasih juga disampaikan kepada Dinas Pertambangan dan Energi Provinsi Papua Barat, Bagian Perekonomian Sekretariat Daerah Kabupaten Manokwari, dan Dinas Pendapatan Pengelolaan Keuangan dan Aset Daerah Kabupaten Manokwari. Apabila terdapat kekeliruan dalam artikel ini, sepenuhnya menjadi tanggung jawab penulis.

\section{DAFTAR PUSTAKA}

Iktama, S. dan Pusposari, D. Analisis Potensi Dan Efektivitas Pemungutan Pajak Mineral Bukan Logam Dan Batuan Di Kabupaten Tuban, Jurnal Ilmiah Mahasiswa FEB Universitas Brawijaya, Vol 1 No 1, 2012, pp. 1-15.

Kemendagri, (1996). Kepmendagri No.690.900.327 Tahun 1996, Tentang Pedoman Penilaian dan Kinerja Keuangan.

Kemenkeu. (2013). Nota Keuangan dan RAPBN Tahun Anggaran 2013, Kementerian Keuangan Republik Indonesia.

PP No. 29 Tahun 2009, Tentang Tata Cara Penentuan Jumlah, Pembayaran, dan Penyetoran PNBP Yang Terutang.

PP No. 45 Tahun 2003 tentang Tarif Atas Jenis Penerimaan Negara Bukan Pajak Yang Berlaku Pada Departemen Energi dan Sumber Daya Mineral.

PP No. 9 Tahun 2012 tentang Jenis dan Tarif Atas Jenis PNBP Yang Berlaku Pada Kementerian Energi dan Sumber Daya Mineral.

UU No. 20 Tahun (1997), Tentang Penerimaan Negara Bukan Pajak. 